\title{
Pengembangan Instrumen Penilaian Sikap Mahasiswa PG-PAUD FIP Unimed dalam Pembelajaran Daring
}

\author{
Roni Sinaga \\ Dosen Program Studi PG PAUD FIP UNIMED \\ Jl. Williem Iskandar Pasar V Medan Estate, Medan, Sumatera Utara,20371
}

Email: ronisinaga@unimed.ac.id

\begin{abstract}
Abstrak - Penilaian sikap dalam pembelajaran daring akibat dampak dari munculnya virus corona menghadirkan tantangan kepada dosen di lingkungan PG-PAUD Fakultas Ilmu Pendidikan UNIMED, dimana instrumen tersebut belum ada, maka pengembangan diperlukan untuk menciptakan instrumen penilaian sikap mahasiswa dalam menjalankan pembelajaran daring. Penelitian ini bertujuan mengembangkan instrumen penilaian sikap mahasiswa PGPAUD Fakultas Ilmu Pendidikan UNIMED dalam pembelajaran daring, pengembangan instrumen dilakukan dengan metode penelitian yang dikembangkan Borg \& Gall dengan tahapan (1) Research and information collecting, (2) Planning, (3) Develop preliminary form of product, (4) Preliminary field testing, (5) Main product revision, (6) Main field testing, (7) Operational product revision, (8) Operational field testing, (9) Final product revision, (10) Dissemination and implementation. pengembangan instrumen dilakukan berdasakan SNPT yang tertuang dalam Permenristekdikti no 44 tahun 2015, serta mempedomani panduan penyusunan kurikulum Pendidikan tinggi di era industri 4.0. subjek yang terlibat dalam penelitian ini terdiri dari ahli materi dan dosen PG-PAUD. Pengumpulan data dilakukan dengan menggunakan wawancara, instrumen skala penilaian dan daftar ceklis. Teknik analisis data dilakukan dengan analisis deskriptif kuantitatif. Produk akhir yang diperoleh setelah melalui keseluruhan tahap dalam metode penelitian sudah layak digunakan dengan kriteria baik, dimana Hasil uji coba pada kelompok kecil diperoleh nilai rata-rata 4,20 (baik) dan kelompok besar dengan nilai rata-rata 4,4 (baik). produk akhir berupa instrumen penilaian sikap di unggah kedalam google form yang dapat dengan mudah diakses dan diimplementasikan pada pembelajaran daring.
\end{abstract}

Kata Kunci: Instrumen, penilaian sikap, Model $R \& D$

\section{Pendahuluan}

Pembelajaran di awal tahun 2020 dihadapkan pada tantangan akibat munculnya virus corona, kemunculan virus ini tentu saja berpengaruh besar pada segala lini kehidupan masyarakat dunia, Indonesia merupakan salah satu negara yang terkena dampak dari virus corona ini dimana melalui Surat Edaran No. 36962/MPK.A/HK/2020 yang dikeluarkan Menteri Pendidikan dan Kebudayaan yang menyatakan bahwa pembelajaran dilakukan dari rumah. kebijakan ini tentunya berlaku bagi seluruh jenjang Pendidikan di Indonesia dan Universitas Negeri Medan mealui surat edaran Rektor UNIMED No.000809/UN33/SE/2020 
juga turut melakukan kebijakan tersebut. pelaksanaan pembelajaran dari rumah atau dengan istilah lainnya pembelajaran daring di lingkungan Universitas Negeri Medan dilakukan dengan memanfaatkan jaringan internet dan aplikasi LMS (Learning Management System) seperti SIPDA, Google Classroom, Edmodo, Schology, serta aplikasi untuk pertemuan virtual seperti Google Meet dan Zoom bahkan juga aplikasi sosial media seperti Whatsapp, e-mail, dan Youtube. dukungan dari layanan tersebut memang dapat memenuhi kebutuhan dalam pembelajaran daring namun hal tersebut bukan berarti terlepas dari kekurangan yang ada didalamnya, yaitu adalah minimnya interaksi langsung sehingga dosen akan kesulitan melihat secara langsung bagaimana sikap dari mahasiswa dalam mengikuti pembelajaran, padahal sikap merupakan salah satu komponen dari unsur penilaian mahasiswa, bukan hanya pengetahuan dan keterampilan saja. kehadiran pembelajaran daring yang secara tiba-tiba tentu saja memberikan tantangan kepada dosen PG-PAUD, Fakultas Ilmu Pendidikan, Universitas Negeri Medan untuk mempersiapkan alat ukur atau instumen penilaian sikap mahasiswa.

Standar sikap mahasiswa berdasarkan standar nasional perguruan tinggi dalam Permenristekdikti no 44 tahun 2015 mencakup sepuluh sikap, yaitu: (a) Bertakwa kepada Tuhan Yang Maha Esa dan mampu menunjukkan sikap religius; (b) Menjunjung tinggi nilai kemanusiaan dalam menjalankan tugas berdasarkan agama, moral, dan etika; (c) Berkontribusi dalam peningkatan mutu kehidupan bermasyarakat, berbangsa, bernegara, dan kemajuan peradaban berdasarkan Pancasila; (d) Berperan sebagai warga negara yang bangga dan cinta tanah air, memiliki nasionalisme serta rasa tanggungjawab pada negara dan bangsa; (e) Menghargai keanekaragaman budaya, pandangan, agama, dan kepercayaan, serta pendapat atau temuan orisinal orang lain; (f) Bekerja sama dan memiliki kepekaan sosial serta kepedulian terhadap masyarakat dan lingkungan; (g) Taat hukum dan disiplin dalam kehidupan bermasyarakat dan bernegara; (h) Menginternalisasi nilai, norma, dan etika akademik; (i) Menunjukkan sikap bertanggungjawab atas pekerjaan di bidang keahliannya secara mandiri; dan (j) Menginternalisasi semangat kemandirian, kejuangan, dan kewirausahaan. berdasarkan standar sikap 
yang dijelaskan diatas dan mengingat kebutuhan akan adanya instrumen penilaian sikap mahaswa maka perlu dilakukan pengembangan instrumen penilaian sikap mahasiswa PG-PAUD 2017 pada mata kuliah Metodologi Penelitian dalam pembelajaran daring.

\section{Kajian Teori}

Pengembangan instrumen penilaian sikap dilaksankaan berdasarkan Standar Nasional Perguruan Tinggi yang tertuang dalam Permenristekdikti no 44 tahun 2015 dan berdasarkan panduan penyusunan kurikulum pendidikan tinggi di era industri 4.0, sepuluh sikap tersebut adalah:

\section{a. Bertakwa Kepada Tuhan Yang Maha Esa Dan Mampu Menunjukkan Sikap Religius}

Sikap religius berkaitan erat dengan sila pertama dalam pancasila yaitu Ketuhanan Yang Maha Esa, nilai-nilai pada sila pertama ini sangat cocok untuk mewakili sikap religius di kehidupan masyarakat yang majemuk. Nilai adalah suatu keyakinan seseorang yang mendasarinya berperilaku(Walborn, 2014) sehingga nilai dapat juga dikatakan sebagai patokan normative seseorang dalam kehidupannya, Bertakwa kepada Tuhan menempati posisi pertama dalam urutan pancasila, tentu saja hal ini karena sila pertama menjiwai dan mendasari sila selanjutnya, artinya Bertakwa kepada Tuhan adalah suatu hal yang sangat paling dasar dan menjiwai nilai-nilai yang lain, sehingga nilai ini sangat penting perannya dalam kehidupan seluruh masyarakat, Bertakwa adalah terpeliharanya diri untuk tetap taat melaksanakan perintah Allah dan menjauhi segala larangan-Nya(KBBI, 2016), Nilai Ketuhanan atau bertakwa kepada Tuhan yang maha esa yang tercermin dalam sikap religius merupakan perilaku yang didasarkan pada aturan atau nilai-nilai yang terkandung dalam agama yang diyakini karena setiap agama pastinya memberikan suatu aturan dasar yang harus dipatuhi oleh umatnya sehingga setiap penganutnya akan berupaya untuk menjauhi larangan dan menjalankan perintah sesuai ajaran agamanya, agama juga memberikan pengetahuan tentang Tuhan-nya hal ini menjadi dasar seseorang untuk percaya akan Tuhan adalah adanya pengetahuan tentang agamanya, dan dalam agama kita 
mengenal istilah iman atau keyakinan yang dibenarkan dihati sehingga mengikuti aturan dengan tulus dan ikhlas, sehingga dari penjelasan tersebut dapat dikembangkan bahwa seseorang yang bertakwa kepada Tuhan memiliki perilaku untuk taat akan ajaran agamanya, memiliki pengetahuan dalam agamanya dan meyakini ajaran agamanya.

Bertakwa kepada Tuhan yang Maha Esa dengan menunjukkan sikap religius dapat dilihat berdasarkan perilaku yang didasarkan pada aturan nilai yang terkandung dalam agama yang diyakini, pengetahuan akan Tuhannya dan iman atau keyakinan sehingga mengikuti aturan dalam agama secara iklas dan tulus. perilaku bertakwa kepada Tuhan yang Maha Esa dapat di observasi berdasarkan perilaku:

1. Berdoa sebelum dan sesudah melaksanakan perkuliahan

2. Percaya kepada Tuhan dengan mengucap syukur dalam Tugas yang dikerjakannya

3. Toleransi beragama antar pemeluk agama yang lain

\section{b. Menjunjung Tinggi Nilai Kemanusiaan Dalam Menjalankan Tugas Berdasarkan Agama,Moral, Dan Etika;}

Nilai kemanusiaan adalah nilai yang berkaitan dengan harkat dan martabat manusia, nilai kemanusiaan yang tinggi ditunjukkan melalui perilaku yang selayaknya manusia yang merupakan ciptaan Tuhan yang memiliki derajatnya lebih tinggi dari mahluk lainnya, dan menghindari perilaku yang merendahkan manusia lain. Nilai kemanusiaan menyangkut kelakuan dan perbuatan manusia yang sesuai dengan norma dan menghormati martabat manusia lainnya(Koentjaraningrat, 1976) Nilai kemanusiaan seseorang dapat dilihat dari hubungan seorang manusia dengan manusia lainnya, Tuhan, dan dengan alam sekitarnya(B Nurgiyantoro, 2010). hubungan tersebut didasarkan pada nilai Kebenaran, Kedamaian, Cinta Kasih, Kebajikan, dan Tanpa Kekerasan. Kemanusiaan adalah perilaku welas asih, simpatik, murah hati atau memposisikan kualitas keadaan sebagai manusia(Merriam-Webster, 2008),sehingga dapat disimpulkan nilai kemanusiaan tidak hanya ditujukan kepada orang lain namun juga kepada Tuhan dan alam sekitarnya, Seseorang dengan nilai kemanusiaan pasti memiliki hubungan yang baik dengan Tuhannya, dan memandang orang lain 
seperti memandang diri sendiri sehingga tidak ada rasa ingin berperilaku negatif atau menurunkan harkat dan martabat orang lain, dan nilai kemanusiaan seseorang juga muncul ketika berinterkasi dengan alamnya, bagaimana memperlakukan hewan atau tumbuhan disekitarnya, menjaga lingkungan sekitarnya.

Nilai kemanusiaan Mahasiswa dapat dilihat dari hubungan seorang manusia dengan manusia lainnya, Tuhan, dan dengan alam sekitarnya,hubungan tersebut didasarkan pada nilai Kebenaran, Kedamaian, Cinta Kasih, Kebajikan, dan Tanpa Kekerasan, mahasiswa yang menjunjung tinggi kemanusiaan dapat memperlakukan orang lain sesuai dengan harkat dan martabatnya, sehingga mahasiswa tersebut dapat dilihat sisi kemanusiaannya dari beberapa perilaku berikut ini:

1. Tidak Membully teman

2. Membantu teman ketika mengalami kesulitan

3. Berupaya mendamaikan teman yang memiliki konflik

\section{c. Berkontribusi Dalam Peningkatan Mutu Kehidupan Bermasyarakat, Berbangsa, Bernegara, Dan Kemajuan Peradaban Berdasarkan Pancasila;}

Berkontribusi dalam peningkatan mutu kehidupan bermasyarakat, berbangsa, Bernegara dan Kemajuan Peradaban Berdasarkan Pancasila adalah perilaku mahasiswa yang turut berperan dalam hal yang disebut diatas melalui kegiatan yang sesuai bidang keahliannya melalui pendidikan, penelitian dan pengabdian kepada masyarakat. peningkatan mutu berkaitan dengan kualitas barang dan jasa yang diberikan atau dihasilkan dan tentunya berkaitan juga dengan kepuasan dari penerima atau pengguna barang dan jasa tersebut. Mutu adalah kesesuaian produk dengan syarat yang ditentukan, kesesuaian adalah kemampuan produk layanan atau proses memenuhi spesifikasi yang diinginkan pelanggan.(Crosby, 2005) mutu dapat juga dikatakan sebagai kualitas yang diartikan sebagai keadaan dinamik yang diasosiasikan dengan produk, jasa, orang, proses, dan lingkungan yang mencapai atau melebihi harapan.(Goetsch \& Davis, 2003) dalam hal ini mahasiswa tentu harus mengetahui kebutuhan dan keinginan masyarakat yang sesuai dengan 
keahliannya dan berupaya dalam pemenuhannya. dari definisi tersebut dapat dipahami bahwa mutu berpatokan pada proses dan hasil namun penilaian dari mutu tetap pada output atau hasil dari proses yang dilakukan, mahasiswa yang berkontribusi dalam peningkatan mutu ditandai dengan kemampuan mahasiswa tersebut dalam menciptakan karya yang dibutuhkan dan diinginkan masyarakat dalam bidang pendidikan.

Peningkatan mutu yang dilakukan oleh mahasiswa adalah berkaitan dengan keahliannya sebagai seorang pendidik, maka peningkatan tersebut dapat berupa penyediaan barang (produk) atau jasa yang mengutamakan kepuasan dari masyarakat sebagai penerima layanan, peningkatan mutu dapat diamati dari perilaku mahasiswa dalam proses melaksanakan tugas dimana pengerjaan tugas tersebut seharusnya memiliki kualitas yang diharapkan, tidak hanya terpatok pada tugas saja namun juga pada kegiatan lainnya seperti penelitian, pengajaran dan pengabdian yang didasarkan pencapaian kualitas yang baik melalui proses yang berkualitas juga. peningkatan mutu tersebut dapat dilihat melalui perilaku seperti:

1. Mengerjakan tugas dengan proses dan produk berkualitas.

2. Mengikuti proses perkuliahan dengan sungguh-sungguh dan mendapatkan nilai yang baik pada saat ujian

3. Mampu melakukan kegiatan yang berkontribusi penyelesaian masalah di masyarakat.

d. Berperan Sebagai Warga Negara Yang Bangga Dan Cinta Tanah Air, Memiliki Nasionalisme Serta Rasa Tanggungjawab Pada Negara Dan Bangsa;

Nasionalisme adalah pandangan tentang rasa cinta yang wajar terhadap bangsa dan negara sekaligus menghormati bangsa lain(Kementerian Pendidikan dan Kebudayaan, 2017) nasionalisme dapat juga diartikan kehendak untuk bersatu dan bernegara,(Renan, 2013) dasar nilai-nilai nasionalisme adalah pancasila. nasionalisme berkaitan erat dengan sila ke 3 dari Pancasila yaitu persatuan Indonesia, ciri-ciri perilaku nasionalisme didasarkan pada rasa cinta dan rela berkorban kepada bangsa, rasa bangga kepada bangsa dan mengutamakan kepentingan bangsa diatas kepentingan kelompok atau pribadi. Mahasiswa diharapkan mampu meunjukkan jiwa nasionalisme sebagai upaya untuk 
mempertahankan kedaulatan bangsa, pada saat ini sudah banyak ideologi dari luar yang berkembang di Indonesia sehingga mengancam kesatuan, di sisi lain kondisi bangsa kita masih tertinggal dari sisi pendidikan dibandingkan dengan negara lain, setiap warga negara seharusnya melakukan peran masing-masing untuk kemajuan bangsa, pada mahasiswa unimed tentu peran yang harus diambil adalah menjaga persatuan dan mengupayakan perubahan dalam mengejar ketertinggalan bangsa kita sebagai wujud cinta tanah air dan tanggungjawab pada negara.

Perilaku nasionalisme didasarkan pada rasa cinta dan rela berkorban kepada bangsa, rasa bangga kepada bangsa dan mengutamakan kepentingan bangsa diatas kepentingan kelompok atau pribadi. mahasiswa yang berjiwa nasionalis akan menjunjung tinggi bangsanya tanpa harus merendahkan bangsa lain, sebagai mahasiswa tentu perilaku nasionalisme diwujudkan dengan mengupayakan segala tindakan yang berkontribusi dalam membangun negara, Perilaku mahasiswa yang memiliki nasionalisme dapat diamati dengan menunjukkan perilaku:

1. Menggunakan bahasa Indonesia dengan baik dan benar

2. Menghargai perbedaan latar belakang sosial

3. Mengikuti Perkuliahan dengan serius demi mewujudkan pendidikan yang dibutuhkan di masyarakat

\section{e. Menghargai Keanekaragaman Budaya, Pandangan, Agama, Dan}

\section{Kepercayaan, Serta Pendapat Atau Temuan Orisinal Orang Lain}

Menghargai sesuai judul diatas adalah perilaku menghormati, menghargai, mengindahkan, memuliakan, dan menjunjung tinggi atas pendapat dan temuan orang lain serta perbedaan diantara sesama. cara menghargai dapat diwujudkan melalui memperlakukan orang lain seperti memperlakukan diri sendiri, menunjukkan sikap beradab dan sopan, Mendengarkan apa yang dikatakan orang lain, Tidak menghina orang lain, Tidak mengancam orang lain, dan Tidak mengenal orang sebelum mengenalnya dengan baik(Samani, 2012). Negara kita terkenal dengan kemajemukannya, hal ini seringkali dianggap sebagai hambatan dalam kejuan bangsa, namun jika dipahami lebih dalam sebenarnya kemajemukan ini adalah anugrah indah dari Tuhan yang harus dijaga, tiap orang seharusnya bahu-membahu saling membantu menjaga persatuan bukannya bersikap egois dan 
hanya menganggap suku atau agamanya saja yang paling benar. saat ini perjuangan bangsa kita justru bukannya ancaman bangsa lain, namun hasutan dari berbagai pihak yang membuat kegaduhan dengan memfokuskan kita pada perbedaan, tentu hal ini harus diubah dengan memunculkan sikap saling menghargai keanekaragaman, sikap menghargai ini tidak hanya akan menjaga kesatuan bangsa, namun juga akan berkontribusi pada lingkungan yang memungkinkan mahasiswa memajukan pendidikan dimana mahasiswa dapat bertukar pikiran melalui pendapat dan setiap karya pendidikan mereka dihargai dengan selayaknya, kondisi inilah yang diharapkan muncul dengan menerapkan sikap saling meghargai.

Dalam keberagaman tentu menghargai keanekaragaman, pendapat dan temuan orisinil orang lain perlu dilakukan dengan tidak membeda-bedakan teman berdasarkan suku dan agama, tidak menghina suku dan agama yang berbeda, atau melarang orang lain untuk beribadah, begitu pula dalam mengemukanan pendapat, mahasiswa perlu untuk menghargai pendapat temannya dengan menanggapinya secara wajar, menghargai temuan orisinil orang lain juga perlu dilakukan dengan tidak melakukan plagiat atas krya orang lain, atau bahkan mengklain itu adalah milik atau temuannya, sikap menghargai pada mahasiswa dapat diamati melalui perilaku:

1. Tidak diskriminatif kepada orang lain

2. Menghargai pendapat dan kritik yang diberikan oleh orang lain

3. Tidak melakukan plagiat atas karya orang lain.

\section{f. Bekerja Sama Dan Memiliki Kepekaan Sosial Serta Kepedulian Terhadap Masyarakat Dan Lingkungan}

Kerja sama adalah Proses sosial dimana didalamnya terdapat aktivitas tertentu untuk mencapai tujuan bersama dengan saling membantu dan saling memahami aktivitas masing-masing(Abdulsyani, 2012), Kepekaan Sosial adalah bagian karakter dalam diri seseorang untuk mudah terangsang terhadap lingkungan sekitarnya, dimana kepekaan sosial tersebut berhubungan dengan Empati dan Kepedulian Sosial. Kepedulian adalah sifat yang membuat pelakunya merasakan apa yang dirasakan orang lain, mengetahui bagaimana rasanya jadi orang lain, kadang ditunjukkan dengan tindakan memberi atau terlibat dengan orang lain 
tersebut(Mu'in, 2011). Mahasiswa dalam perkuliahan dapat menunjukkan sikap bekerjasama terutama pada saat kerja kelompok, setiap mahasiswa juga dituntut peka dan peduli terhadap lingkungannya, hal ini tentu berkaitan dengan kemampuan mahasiswa dalam menganalisis lingkungan dan menemukan masalah pada lingkungannya dan berupaya menyelesaikan dengan penelitian atau tindakan yang berdasar pada ilmu yang dipelajarinya, mahasiswa yang mampu bekerjasama biasanya di tandai dengan kualitas dari tugas yang kelompok mereka kerjakan da nada tidaknya konflik pada kelompok tersebut dalam menyelesaikan tugasnya, dan tinggi rendahnya tingkat kepekaan dan kepedulian mahasiswa akan lingkunan sekitarnya dapat dilihat berdasarkan pengerjaan tugas yang sesuai dengan permasalahan yang ada di lingkungannya

Kerjasama yang baik dapat diwujudkan dengan adanya hubungan yang baik antar sesama tim, kerjasama yang baik juga dapat dilihat berdasarkan produktifitas kinerja tim dalam melaksanakan tanggungjawabnya misalnya saat mengerjakan kerja kelompok, dan juga setiap mahasiswa harus peka dan peduli dengan perubahan yang terjadi dilingkungan, selama perkuliahan kepekaan dan kepedulian ini dapat dilihat dari perhatian dan kontribusi dari mahasiswa ketika mengerjakan tugas kelompok dan tentunya dengan adanya kepekaan dan kepedulian akan menghasilkan hubungan yang baik antar anggota kelompok dan meningkatnya produktifitas kerja, Bekerja sama, kepekaan dan kepedulian sosial diwujudkan dalam perilaku:

1. Mau ikut berpartisipasi aktif dalam pengerjaan tugas kelompok

2. Mampu bekerjasama sebagai tim dalam tugas kelompok

3. Mampu menemukan masalah pendidikan di lingkungan sekitarnya

\section{g. Taat Hukum Dan Disiplin Dalam Kehidupan Bermasyarakat Dan Bernegara;}

Kemajuan dari suatu bangsa dapat dilihat dari kesadaran masyarakatnya dalam mentaati hukum, taat hukum adalah perilaku yang sesuai dengan tuntutan instrumen yang mengatur tingahlaku masyarakat dalam pergaulan hidup(Achmad Ali, 2010), perilaku taat hukum tentunya tidak hanya kepada Undang-undang dan 
peraturan di masyarakat, namun juga peraturan di lingkungan kampus dan perkuliahan, Disiplin adalah perilaku atau sikap yang sesuai dengan peraturan. sehingga dapat dikatakan taat aturan sama dengan disiplin, seseorang dengan disiplin tinggi biasanya menunjukkan sikap Tidak lalai atas tugasnya, dan produktivitas yang tinggi. Pada saat ini dilingkungan sekitar setiap harinya dapat kita lihat pelanggaran pada aturan, sehingga perubahan untuk taat hukum dan disiplin itu perlu untuk di tingkatkan, selama masa perkuliahan tentunya mahasiswa memahami aturan yang dijelaskan dalam RPS yang disepakati bersama dengan Dosen, mengikuti peraturan yang sederhana pada lingkungannya akan berdampak pada internalisasi nilai tersebut pada diri mahasiswa sehingga nantinya ketika dimasyarakat akan terbiasa untuk patuh pada aturan dan disiplin. mahasiswa yang taat aturan dan disiplin tentu dapat dilihat dari perilakunya dalam pengerjaan tugas apakah tepat waktu atau terlambat dan mengikuti seluruh kegiatan perkuliahan sesuai RPS atau tidak. Aturan yang ditetapkan tentu bertujuan untuk menjaga ketertiban dan keteraturan dari lingkungan, tanpa ketertiban tentu kualitas dari pembelajaran akan menurun dan berpengaruh pada capaian pembelajaran mahasiswa tersebut.

Tujuan dibuatnya aturan adalah untuk menghindari kekacauan, ada banyak aturan yang mengikat perilaku dari manusia, mahasiswa biasayan memiliki aturan dari universitas yang mengatur bagaimana mahasiswa tersebut berperilaku di lingkungan kampus. Perilaku mahasiswa yang Taat hukum dan disiplin dapat diamati melalui perilaku:

1. Mengikuti peraturan dan kesepakatan perkuliahan di RPS

2. Tidak lalai atas tugas yang diberikan kepada mahasiswa

3. Mengerjakan tugas sesuai dengan batas waktu yang ditentukan

\section{h. Menginternalisasi Nilai, Norma, Dan Etika Akademik}

Nilai adalah apa yang dianggap baik, layak, pantas, benar, penting, indah, dan dikehendaki oleh masyarakat(Giddens, 1991). Norma adalah aturan berperilaku dalam kehidupan bermasyarakat yang berisi perintah dan larangan agar terwujud kemanan, ketertiban dan kedamaian(Clark, 1947). Etika adalah baik buruknya perilaku yang ditampilkan dalam kehidupan sosial(Pusat Bahasa Kemdikbud, 
2016). ketiga komponen tersebut harus di internalisasi, internalisasi adalah penghayatan atas nilai, norma dan etika sehingga terwujud dalam sikap dan perilaku mahasiswa, perilaku tersebut dapat diamati dari durasi, frekuensi dan intensitasnya. jika seorang mahasiswa tidak memiliki nilai, norma dan etika maka sudah pasti kelak mahasiswa tersebut akan menjadi ancaman bagi negara, karena dia akan berperilaku buruk, melanggar aturan masyarakat dan tidak mampu menampilkan sikap yang pantas di lingkungan sosialnya sama seperti pada koruptor yang memiliki kapasitas tinggi dalam pengetahuan namun rendah dalam penghayatan nilai, norma dan etika. dalam penerapan nilai, norma dan etika juga sering terjadi kekeliruan pada yang mengamatinya, atau disebut juga pencitraan, sehingga orang yang mengamati tertipu akan perilaku tersebut. maka durasi, frekuensi dan intensitas dari perilaku yang menunjukkan nilai, norma dan etika juga perlu diperhatikan.

Seorang mahasiswa yang meiliki nilai, norma dan etika akademik dalam dirinya akan memunculkan periaku yang sesuai secara terus menerus, Menginternalisasi nilai, norma dan etika akademik mahasiswa diamati melalui frekuensi, intensitas dan durasi pelaksanaan dari perilaku tersebut selama perkuliahan, perilaku mahasiswa tersebut dapat diamati melalui:

1. Selama perkuliahan berpakaian rapi dan sesuai dengan aturan perkuliahan

2. Selama perkuliahan mampu berkomunikasi dengan sopan dan santun

3. Selama perkuliahan mampu menunjukkan perilaku yang sopan dan santun

i. Menunjukkan Sikap Bertanggungjawab Atas Pekerjaan Di Bidang

\section{Keahliannya Secara Mandiri}

Bertanggungjawab merupakan perbedaan antara benar dan salah, boleh dilakukan dan dilarang serta kesadaran menghindari segala sesuatu yang bersifat negatif dan berupaya untuk melakukan hal-hal yang positif(Abu \& Soleh, 2005), bertanggungjawab dapat juga dijelaskan sebagai kemampuan untuk membuat keputusan yang pantas dan efektif(Wiyoto, 2001), bertanggungjawab merupakan perilaku yang menentukan bagaimana bereaksi setiap hari yang didasarkan pada keputusan bersifat moral(Schiller \& Bryant, 2002). Bertanggungjawab memiliki beberapa aspek yaitu: Kesadaran, Kecintaan dan kesukaan, Keberanian $(\mathrm{H}$ 
Burhanuddin, 2000). dari pendapat tersebut dapat disimpulkan bertanggungjawab adalah perilaku yang ditunjukkan seseorang dalam kehidupan sehari-hari yang berdasarkan moral dan didasari oleh kesadaran, tanpa paksaan, dan keberanian. Mahasiswa yang bertanggungjawab tentu dapat dilihat dari perilakunya dalam menyelesaikan tanggungjawabnya sebagai mahasiswa, seperti mengerjakan tugas, mengikuti ujian, belajar, menghadiri perkuliahan dan sebagaianya. tanggung jawab tersebut dilakukan tanpa harus diingatkan selalu karena adanya kesadaran untuk melakukannya bahwa tanggungjawab tersebut jika dilakukan akan berdampak pada dirinya, dan tidak melaksanakannya karena terpaksa karena memikirkan konsekuensi jika tidak melakukan tanggungjawabnya, mahasiswa yang bertanggungjawab juga dapat dilihat dari kemampuannya untuk menerima konsekuensi dari kesalahan yang dilakukannya tanpa harus menyalahkan orang lain dan memberikan alasan-alasan yang belum tentu benar. Kriteria mahasiswa bertanggungjawab atas pekerjaannya di bidang keahlian secara mandiri dapat dinilai dari tiga komponen tersebut, yaitu: adanya kesadaran, tidak ada rasa terpaksa dan mampu menerima konsekuensi.

Perilaku bertanggungjawab pada mahasiswa ditandai dengan kemampuan mahasiswa tersebut untuk menerima konsekuensi atau kelalaiannya dalam melaksanakan tanggungjawab, selain itu mahasiswa yang bertanggungjawab akan melaksanakan tanggungjawabnya dengan kesadaran dimana tidak perlu diingatkan terus menerus dan memahami hal tersebut adalah untuk kepentingan diri sendiri, disisi lain melakukan tanggungjawab tanpa paksaan adalah salah satu sikap bertanggungjawab. Mahasiswa yang bertanggungjawab dapat dilihat dari tiga aspek yaitu kesadaran, tidak ada paksaan, dan menerima konsekuensi. dalam perkuliahan perilaku Bertanggungjawab dapat ditunjukkan melalui perilaku:

1. Mengerjakan seluruh 6 jenis tugas dalam KKNI, Mengikuti Perkuliahan setiap pertemuan dan Mengikuti Ujian Tengah Semester dan Ujian Akhir Semester

2. Mengkuti seluruh kegiatan perkuliahan tanpa merasa paksaan

3. Menerima konsekuensi atas kelalaian memenuhi tanggungjawab 


\section{j. Menginternalisasi Semangat Kemandirian, Kejuangan, Dan} Kewirausahaan.

Kemandirian adalah kondisi dimana seseorang tidak ketergantungan pada orang lain dalam menentukan keputusan dan adanya sikap percaya diri(Chaplin, 2011), Kejuangan adalah konsep yang berkaitan dengan sifat, mutu, kedaan tertentu yang berguna bagi manusia dan kemanusiaan yang menyangkut upaya tak kenal lelah untuk tetap eksis secara bermartabat. Kewirausahaan adalah ilmu yang mengkaji tentang pengembangan dan pembangunan semangat kreatifitas serta berani menanggung resiko terhadap pekerjaan yang dilakukan demi mewujudkan hal tersebut atau menciptakan bisnis baru dengan mengambil resiko dan ketidakpastian demi mencapai keuntungan dan pertumbuhan dengan cara mengidentifikasi peluang dan menggabungkan sumber daya yang diperlukan untuk mendirikannya(Scarborough \& Zimmerer, 2011). Mahasiswa diharapkan dapat bersikap mandiri dalam perkuliahan dengan tidak bergantung terlalu banyak kepada orang lain, mengupayakan solusi atas kendala atau masalah dalam perkuliahannya, serta mampu melihat peluang wirausaha dari sisi dunia pendidikan dengan memunculkan gagasan kewirausahaan atau melaksanakan kegiatan yang dapat digunakan sebagai kegiatan wirausaha.

Mahasiswa dengan perilaku mandiri tentu tidak akan sering bergantung pada orang lain akan suatu hal Selama hal tersebut masih dalam batas kemampuan mahasiswa tersebut, misalnya mengerjakan sendiri tugas yang diberikan padanya, bukannya melimpahkan atau mengupahkan tugas nya kepada orang lain, mahasiswa yang memiliki semangat kejuangan di tunjukkan dengan upaya-upaya yang ditempuh mahasiswa tersebut untuk tetap ikut dalam perkuliahan, dan mahasiswa yang memiliki semangat kewirausahaan ditandai dengan kemampuan mahasiswa tersebut dalam memberikan gagasan yang berkaitan dengan kewirausahaan atau menciptakan produk yang berhubungan dengan kegiatan kewirausahaan. Menginternalisasi semangat kemandirian, kejuangan dan kewirausahaan diamati melalui perilaku: 
1. Mampu menlaksanakan tugas perkuliahan sendiri tanpa menyuruh orang lain

2. Berupaya mengatasi masalah-masalah dalam mengikuti perkuliahan

3. Mampu memunculkan ide atau produk yang berorientasi kewirausahaan

berdasarkan dengan panduan penyusunan kurikulum Pendidikan tinggi di era industri 4.0 pengembangan instrumen penilaian sikap sebaiknya dilakukan dengan observasi dimana penilaian dilakukan oleh Dosen, teman sekelas, dan diri sendiri, sehingga diperoleh gambaran yang lebih tepat dan jelas.

\section{Metode Penelitian}

Desain penelitian ini menggunakan desain penelitian pengembangan oleh Borg \& Gall yang dilakukan melalui sepuluh tahap pengembangan yang dijelaskan pada gambar berikut ini:

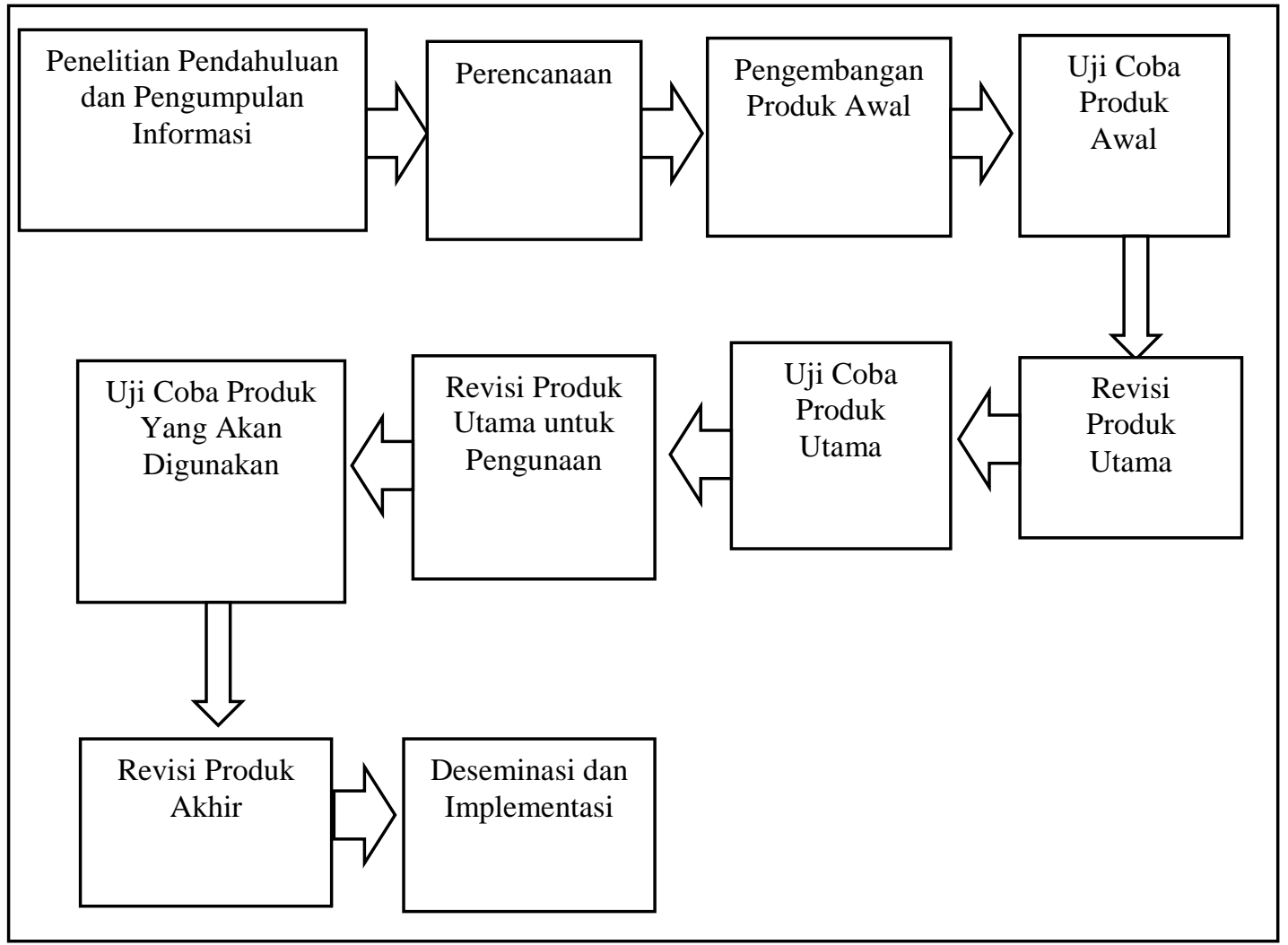

Gambar 1. Tahapan Pengembangan perangkat Pembelajaran Metodologi

Penelitian (Gall, M. D., Gall, J. P., \& Borg, 2003) 
Penelitian ini dilakukan pada semester genap tahun akademik 2019/2020 pada mahasiswa dan dosen prodi PG-PAUD, Fakultas Ilmu Pendidikan, Universitas Negeri Medan yang mengikuti perkuliahan secara daring, dan data dalam penelitian ini diperoleh melalui Observasi, Wawancara dan Dokumentasi

\section{Hasil Penelitian dan Pembahasan Hasil}

Hasil pengembangan Instrumen Penilaian Sikap mahasiswa PG-PAUD dalam pembelajaran daring dapat dilihat pada google form pada link berikut ini:

1. penilaian oleh dosen : https://forms.gle/CtvvUi5Gy3B6cawB6

2. penilaian oleh teman : https://forms.gle/FbNqQHYvnzWwwN1n8

3. penilaian oleh diri sendiri : https://forms.gle/t2CoYsr96qB3WzXd6

\section{Pembahasan}

Peneltian diawali dengan penelitian pendahuluan dan mengumpulkan informasi, pada tahap pertama ini peneliti mengumpulkan informasi melalui wawancara terkait bagaimana prosedur penilaian sikap mahasiswa pada mata kuliah metodologi penelitian dan apakah sudah ada instrumen yang digunakan khusus untuk pembelajaran daring, berdasarkan hasil wawancara ditemukan bahwa penilaian sikap mahasiswa dilakukan dengan mengamati langsung sikap yang ditampilkan mahasiswa selama mengikuti pembelajaran baik secara luring maupun daring, kemudian mencatat keaktifan mereka dalam mengikuti perkuliahan serta kepatuhan mengikuti aturan perkuliahan, dan dengan melalui pengumpulan infromasi juga ditemukan bahwa pada pembelajaran daring, mahasiswa dan dosen sudah akrab dengan google form sebagai media penilaian sikap.

Pada tahap kedua peneliti melakukan perencanaan dengan mengembangkan indikator penilaian sikap mahasiswa kemudian menentukan media yang akan digunakan dalam melaksanakan penilaian sikap mahasiwa, serta menentukan cara penilaian dilakukan, melalui tahap ini peneliti merencanakan indikator penilaianan sikap didasarkan pada sepuluh standar sikap dalam Permenristekdikti no 44 tahun 2015. masing-masing standar dari sikap tersebut dikembangkan dalam tiga variabel pengamatan dengan 5 skala penilaian dengan menggunakan google form sebagai medianya, serta cara penilaian yang direncanakan adalah dengan mengumpulkan 
data dari tiga sumber informasi yaitu data penilaian sikap pmahasiswa yang bersumber dari dosen, teman mahasiswa, dan diri sendiri.

Tahap ketiga peneliti mengembangkan produk awal sesuai dengan rencana awal yang sudah dikembangkan, namun berdasarkan validasi ahli perlu perbaikan pada aspek kalimat agar lebih jelas maksud dan tujuannya, dan pada skala penilaian yang sebelumnya 5 sebaiknya cukup dengan 4 skala penilaian saja.

Pada tahap uji coba produk awal peneliti melakukan uji validasi kepada pakar dan memberikan penilaian terhadap instrumen yang telah disusun, hasil uji coba pakar dapat dilihat pada tabel berikut:

Tabel 1. Hasil uji coba produk awal

\begin{tabular}{|l|l|c|c|c|c|}
\hline \multirow{2}{*}{ No } & \multirow{2}{*}{ Aspek yang dinilai } & \multicolumn{2}{|c|}{ Skor Penilaian } & \multirow{2}{*}{ Rerata } & \multirow{2}{*}{ Keterangan } \\
\cline { 3 - 5 } & & Ahli 1 & Ahli 2 & & \\
\hline 1 & Kejelasan & 4,5 & 4,5 & 4,5 & \\
\hline 2 & Ketepatan isi & 4,5 & 4 & 4,25 & \\
\hline 3 & Relevansi & 4 & 4 & 4 & \\
\hline 4 & Kevalidan isi & 4 & 4 & 4 & \\
\hline 5 & Tidak ada bias & 4 & 4 & 4 & \\
\hline 6 & Ketepatan Bahasa & 3,3 & 4 & 3,65 & \\
\hline & Jumlah & $\mathbf{2 4 , 3}$ & $\mathbf{2 4 , 5}$ & $\mathbf{2 4 . 4}$ & \\
\hline & Rerata & $\mathbf{4 , 0 5}$ & $\mathbf{4 , 0 8}$ & $\mathbf{4 , 0 6}$ & Baik \\
\hline
\end{tabular}

pada tahap uji coba produk awal diperoleh nilai terendah pada aspek ketepatan Bahasa, sedangkan pada aspek lainnya sudah baik, berdasarkan uji coba ini maka dilakukan perbaikan pada aspek Bahasa sehingga Bahasa dalam lembar observasi lebih mudah dipahami, sesudah melakukan perbaikan pada aspek ketepatan Bahasa maka dilanjutkan dengan uji coba produk utama, uji ini dilakukan dengan melibatkan beberapa dosen PG-PAUD dan hasil uji coba produk utama dapat dilihat pada tabel berikut ini:

Tabel 2. Hasil uji coba produk utama

\begin{tabular}{|c|c|c|c|c|c|c|c|c|}
\hline \multirow{2}{*}{ No } & \multirow{2}{*}{ Aspek yang dinilai } & \multicolumn{5}{|c|}{ Penilaian Subjek } & \multirow{2}{*}{ Rerata } & \multirow{2}{*}{$\begin{array}{l}\text { Ketera- } \\
\text { ngan }\end{array}$} \\
\hline & & 1 & 2 & 3 & 4 & 5 & & \\
\hline 1 & Kejelasan & 5 & 4 & 4 & 4 & 4,5 & 4,3 & \\
\hline 2 & Ketepatan isi & 4,5 & 4,5 & 4 & 4,5 & 4 & 4,3 & \\
\hline 3 & Relevansi & 4 & 4 & 4 & 4 & 4 & 4 & \\
\hline 4 & Kevalidan isi & 4 & 4 & 4 & 4 & 4 & 4 & \\
\hline 5 & Tidak ada bias & 5 & 4 & 5 & 4 & 4 & 4,4 & \\
\hline
\end{tabular}




\begin{tabular}{|c|c|c|c|c|c|c|c|c|}
\hline \multirow{2}{*}{ No } & \multirow{2}{*}{ Aspek yang dinilai } & \multicolumn{5}{|c|}{ Penilaian Subjek } & \multirow{2}{*}{ Rerata } & \multirow{2}{*}{$\begin{array}{l}\begin{array}{l}\text { Ketera- } \\
\text { ngan }\end{array} \\
\end{array}$} \\
\hline & & 1 & 2 & 3 & 4 & 5 & & \\
\hline 6 & Kete & 4 & 4 & 4 & 4 & 5 & 4,2 & \\
\hline & & 26,5 & 24,5 & 25 & 24,5 & 25,5 & 25,2 & \\
\hline & Rerata & 4,41 & 4,08 & 4.17 & 4.08 & 4.25 & 4.20 & Baik \\
\hline
\end{tabular}

berdasarkan uji coba tersebut terdapat perubahan pada aspek ketepatan bahasa yang sudah mencapai rerata 4,2 sehingga keseluruhan aspek sudah berada pada nilai yang baik sehinga pengembangan dapat dilanjutkan pada uji coba produk yang akan digunakan, hasil uji coba kelompok besar dapat dilihat pada tabel berikut ini:

Tabel 3. Hasil uji coba produk yang akan digunakan

\begin{tabular}{|l|l|c|c|c|}
\hline Aspek & Indikator & Skor & Rerata & Ket \\
\hline Kejelasan & 1. Kejelasan setiap butir observasi & 97 & 4.4 & Baik \\
\cline { 2 - 5 } & $\begin{array}{l}\text { 2. Kejelasan Petunjuk pengisian lembar } \\
\text { observasi }\end{array}$ & 92 & 4.2 & Baik \\
\hline Ketepatan & $\begin{array}{l}\text { 3. Ketepatan penggunaan bahasa untuk } \\
\text { isi }\end{array}$ & 96 & 4.4 & Baik \\
\cline { 2 - 5 } & $\begin{array}{l}\text { 4. Ketepatan lembar observasi dengan } \\
\text { SNPT }\end{array}$ & 93 & 4.2 & Baik \\
\hline Relevansi & $\begin{array}{l}\text { 5. lembar observasi berkaitan dengan } \\
\text { tujuan pembelajaran }\end{array}$ & 100 & 4.5 & Baik \\
\hline $\begin{array}{l}\text { Kevalidan } \\
\text { isi }\end{array}$ & $\begin{array}{l}\text { 6. Lembar observasi yang digunakan } \\
\text { mengungkapkan informasi yang benar }\end{array}$ & 96 & 4.4 & Baik \\
\hline $\begin{array}{l}\text { Tidak ada } \\
\text { bias }\end{array}$ & $\begin{array}{l}\text { 7. Kalimat lembar observasi tidak } \\
\text { menimbulkan makna ganda }\end{array}$ & 99.5 & 4.5 & Baik \\
\hline $\begin{array}{l}\text { Ketepatan } \\
\text { Bahasa }\end{array}$ & $\begin{array}{l}\text { 8. Bahasa yang digunakan mudah } \\
\text { dipahami }\end{array}$ & 96 & 4.4 & Baik \\
\cline { 2 - 6 } & 9. Bahasa yang digunakan efektif & 98 & 4.5 & Baik \\
\cline { 2 - 5 } & 10. Penulisan sesuai dengan EYD & 103 & 4.7 & Baik \\
\hline
\end{tabular}

hasil uji coba pada kelompok besar menunjukkan hasil yang baik dimana keseluruhan aspek sudah mencapai rerata dengan kategori baik, maka tidak perlu dilakukan lagi revisi sehingga instrumen yang sudah dikembangkan dapat di buat dalam bentuk yang lebih mudah digunakan untuk pembelajaran daring, yaitu dengan membuat instrumen dalam google form. produk penelitian berupa instumen penilaian sikap mahasiswa dalam pembelajaran daring ini disosialisasikan kepada 
seluruh dosen di lingkungan program studi PG-PAUD Fakultas Ilmu Pendidikan, UNIMED.

\section{Simpulan}

Kesimpulan yang diperoleh dari pelaksanaan penelitian ini adalah, penelitian ini berhasil mengembangakan instrumen penilaian sikap mahasiswa PG-PAUD dalam pembelajaran daring, dimana instrumen ini sudah layak digunakan dengan kategori baik, ditinjau dari aspek: kejelasan dengan rerata 4,3, ketepatan isi dengan rerata 4,3, relevansi dengan rerata 4,5, kevalidan isi dengan rerata 4,4, tidak ada bias dengan rerata 4,5, dan ketepatan Bahasa dengan rerata 4,55 dimana keseluruahan rerata tersebut berkategori baik, dan untuk rerata keseluruhan aspek sudah mencapai nilai 4,4 dengan kategori baik.

\section{Daftar Pustaka}

Abdulsyani. (2012). Sosiologi Skematika Teori dan Terapan (4th ed.). BUMI AKSARA.

Abu, A., \& Soleh, M. (2005). Psikologi Perkembangan. Rineka Cipta.

Achmad Ali. (2010). Menguak Teori Hukum (Legal Theory) dan Teori Peradilan (Judicial Prudence) Termasuk Interpretasi Undang-Undang (Legisprudence). In Kencana.

B Nurgiyantoro. (2010). SASTRA ANAK DAN PEMBENTUKAN KARAKTER. https://doi.org/10.21831/cp.v1i3.232

Chaplin, J. (2011). Kamus Lengkap Psikologi. Diterjemahkan: kartini Kartono. PT Raja Grafindo Persada.

Clark, W. D. (1947). Encyclopaedia britannica. In Notes and Queries. https://doi.org/10.1093/nq/192.20.435-a

Crosby, P. B. (2005). Crosby's 14 steps to improvement. In Quality Progress.

Gall, M. D., Gall, J. P., \& Borg, W. R. (2003). Educational research: An introduction (7th ed.). In Boston, MA: A \& B Publications.

Giddens, A. (1991). The consequences of modernity antony giddens. The British Journal of Sociology. https://doi.org/10.2307/591454

Goetsch, D. L., \& Davis, S. (2003). Quality Management: Introduction to Total Quality Management for Production. In British Libary Cataloguing-inPublication Data. https://doi.org/British Library Cataloguing- In Publication data

H Burhanuddin, S. (2000). Etika Individual. Rineka Cipta.

KBBI. (2016). Kamus Besar Bahasa Indonesia ( KBBI ). In Kementerian Pendidikan dan Budaya. 
Kementerian Pendidikan dan Kebudayaan. (2017). Modul Pelatihan Dasar Calon PNS.

Koentjaraningrat. (1976). "Manusia dan Kebudayaan Di Indonesia." In Djambatan. https://doi.org/10.1016/s0044-8486(97)00050-1

Merriam-Webster, I. (2008). Merriam-webster online dictionary. In Springfield, MA: Author. Retrieved July.

Mu'in, F. (2011). Pendidikan Karakter, Konstruksi Teoretik dan Praktik. Ar-Ruzz Media.

Pusat Bahasa Kemdikbud. (2016). Kamus Besar Bahasa Indonesia Edisi Kelima $($ KBBI V). Badan Pengembangan Dan Pembinaan Bahasa, Kementerian Pendidikan Dan Kebudayaan Republik Indonesia.

Renan, E. (2013). What is a nation? In Nation and Narration. https://doi.org/10.4324/9780203388341

Samani, M. dan H. (2012). Konsep dan Model Pendidikan Karakter. PT Remaja Rosdakarya.

Scarborough, N. M., \& Zimmerer, T. W. (2011). Effective Small Business Management. Facilities.

Schiller, P., \& Bryant, T. (2002). the value book of children. teaching 16 basic values to young children (S. Sensusi (ed.); 3rd ed.). Elex Media Komputindo.

Walborn, F. (2014). Gordon Allport. In Religion in Personality Theory. https://doi.org/10.1016/b978-0-12-407864-2.00014-x

Wiyoto, A. (2001). Melatih Anak Bertanggung Jawab. Mitra Utama. 